\title{
Blood Mineral, Hormone, and Osteocalcin Responses of Multiparous Jersey Cows to an Oral Dose of 25-Hydroxyvitamin $D_{3}$ or Vitamin $D_{3}$ Before Parturition
}

\author{
M. S. Taylor, ${ }^{\star}$ K. F. Knowlton, ${ }^{* 1}$ M. L. McGilliard, ${ }^{\star}$ W. M. Seymour, $\dagger$ and J. H. Herbein ${ }^{\star}$ \\ *Department of Dairy Science, Virginia Polytechnic Institute and State University, Blacksburg 24061-0315 \\ †DSM Nutrition, Parsippany, NJ 07054
}

\section{ABSTRACT}

Twenty-seven multiparous Jersey cows were randomly assigned to receive an oral bolus containing corn starch (control, CON), corn starch plus $15 \mathrm{mg}$ of 25 hydroxyvitamin $\mathrm{D}_{3}(25-\mathrm{OH})$, or $15 \mathrm{mg}$ of cholecalciferol $\left(\mathrm{D}_{3}\right)$ at $6 \mathrm{~d}$ before expected parturition. Cows were maintained in individual box stalls from $20 \mathrm{~d}$ before expected parturition and fed a common diet. Jugular blood samples were collected at $-14,-13,-5,-4,-3,-2,-1 \mathrm{~d}$ before expected calving, at calving, and at 1, 3, 5, 7, 9, $11,13,28,56$, and $84 \mathrm{~d}$ postcalving. After calving, cows were housed in 1 pen in a free-stall barn and consumed a common diet. Colorimetric assays were used to analyze $\mathrm{Ca}, \mathrm{P}$, and $\mathrm{Mg}$ concentrations in serum. Serum concentrations of osteocalcin (OC), an indicator of bone formation, serum 25-hydroxyvitamin $\mathrm{D}_{3}$, and parathyroid hormone (PTH) were determined in samples obtained from $d-5$ through $d 13$. The 9 control multiparous cows and 5 untreated primiparous cows were used to evaluate the effect of parity on the variables that were measured. There was no effect of parity on $\mathrm{Ca}$, $\mathrm{PTH}$, or 25-OH concentration. Compared with secondlactation cows and older cows ( $>2$ lactations), first-lactation cows had greater serum OC $(22.3,32.0$, and 48.3 $\mathrm{ng} / \mathrm{mL}$, respectively), indicating that younger animals were forming more bone. Blood $\mathrm{Ca}, \mathrm{P}$, and $\mathrm{Mg}$ decreased near the time of calving and then increased over time. Serum 25-hydroxyvitamin $\mathrm{D}_{3}$ was greater for cows dosed with $25-\mathrm{OH}(119.0 \mathrm{ng} / \mathrm{mL})$ compared with those dosed with $\mathrm{D}_{3}(77.5 \mathrm{ng} / \mathrm{mL})$ or CON $(69.3 \mathrm{ng} / \mathrm{mL})$. Cows dosed with $25-\mathrm{OH}$ tended to have lower serum PTH concentration, but treatments did not affect serum $\mathrm{Ca}, \mathrm{P}$, or $\mathrm{Mg}$. Serum OC was greater in secondlactation cows compared with cows entering their third or fourth lactation but OC was unaffected by treatment. Although results indicated a $60 \%$ increase in serum 25 -

Received October 3, 2007.

Accepted February 15, 2008.

${ }^{1}$ Corresponding author: knowlton@vt.edu hydroxyvitamin $\mathrm{D}_{3}$ due to a single oral dose of $25-\mathrm{OH}$ before calving, the amount administered in this study apparently was not sufficient for initiation of any improvement in $\mathrm{Ca}$ homeostasis at parturition.

Key words: calcium, cow, osteocalcin, hypocalcemia

\section{INTRODUCTION}

Hypocalcemia is a common condition near parturition for $5.2 \%$ of US dairy cows (NAHMS, 2002). Maintenance of blood Ca within the acceptable range of 8 to $10 \mathrm{mg} /$ $\mathrm{dL}$ is a balancing act between the demand for $\mathrm{Ca}$ for milk production and the cow's homeostatic mechanisms to maintain blood $\mathrm{Ca}$. A blood Ca concentration below $5 \mathrm{mg} / \mathrm{dL}$ typically results in parturient paresis, the condition more commonly known as milk fever. As cows age, Ca homeostatic mechanisms react more slowly to the Ca demands of lactation (Horst et al., 1994).

To prevent milk fever in cows, researchers (Hibbs and Pounden, 1951) often recommended feeding or injecting pharmacological doses of vitamin D $2 \mathrm{wk}$ before calving. This practice increases intestinal absorption of $\mathrm{Ca}$ and helps prevent milk fever, but the recommended dose (up to 10 million units/d) of vitamin $\mathrm{D}$ is very close to the amount that causes irreversible metastatic calcification of soft tissue (Littledike et al., 1986).

Vitamin D is a necessary precursor for production of the Ca-regulating hormone 1,25-dihydroxyvitamin $\mathrm{D}_{3}$ (DHVD). Vitamin D can be produced within the skin of most mammals by photochemical conversion of 7 dehydrocholesterol to vitamin $\mathrm{D}_{3}$. The liver has a high affinity for vitamin $\mathrm{D}$ in circulation. In the liver, vitamin $\mathrm{D}$ is hydroxylated into 25-hydroxyvitamin $\mathrm{D}_{3}(\mathbf{2 5}$ OH) by action of microsomal enzymes (Goff et al., 1991). The 25- $\mathrm{OH}$ then enters systemic circulation and is further converted to DHVD in the kidney.

The DHVD hormone increases active transport of $\mathrm{Ca}$ and $\mathrm{P}$ across intestinal epithelial cells and its production is tightly regulated by parathyroid hormone (PTH). Parathyroid hormone has 3 main functions in cows: to mobilize $\mathrm{Ca}$ from bone, to promote absorption of $\mathrm{Ca}$ from the digestive tract through increasing DHVD 
concentration, and to stimulate the kidneys to excrete excess $\mathrm{P}$ while retaining $\mathrm{Ca}$ for reabsorption (Goff, 2000). As blood Ca concentration decreases, PTH concentration increases. High concentrations of PTH promote the production of 1- $\alpha$-hydroxylase in the kidney, the enzyme that converts $25-\mathrm{OH}$ to DHVD. When blood $\mathrm{Ca}$ is within the normal range, $\mathrm{PTH}$ secretion decreases and DHVD is catabolized through a negative feedback mechanism. The 25-OH is diverted to inactive compounds rather than DHVD (Horst et al., 1994). When DHVD or PTH bind to osteoblasts (bone-forming cells), the osteoblasts secrete compounds that activate osteoclasts to resorb bone mineral and return it to the blood. Biochemical markers of bone formation such as osteocalcin (OC) can be measured in the blood to evaluate bone metabolism.

Various forms of vitamin $\mathrm{D}$ and their derivatives have been examined in relation to Ca mobilization and prevention of hypocalcemia (Olson et al., 1973a; Horst et al., 1983; Naito et al., 1990; Hodnett et al., 1992; Okura et al., 2004). Pharmacological doses are effective at preventing hypocalcemia but are close to the toxic dose. Lower doses may actually induce milk fever, depending on timing of administration, because high doses of 25$\mathrm{OH}$ and DHVD suppress renal synthesis of DHVD and suppress release of PTH (Littledike and Horst, 1982). It is speculated that the Jersey breed is more prone to milk fever because they express fewer intestinal DHVD receptors and secrete more $\mathrm{Ca}$ in colostrum and milk (Goff et al., 1995).

The stimulation, regulation, and activation of the homeostatic mechanisms related to Ca metabolism represent a well-orchestrated cascade of events. One exception is the time around parturition when the animal is subject to a dramatic increase in Ca demand concomitant with a delay in the mobilization of $\mathrm{Ca}$. Theoretically, exogenous manipulation of this cascade via vitamin D supplementation should be possible. Despite years of research, the most advantageous form, timing of treatment, and route of administration are still in question and new commercial products such as $25-\mathrm{OH}$ have been developed to address this problem. Our hypothesis was that dosing preparturient cows with exogenous 25-OH $6 \mathrm{~d}$ before parturition would allow $\mathrm{Ca}$ homeostatic mechanisms to be active at parturition. Further, increasing blood Ca before the demand for $\mathrm{Ca}$ by the mammary gland at parturition could attenuate the severity of hypocalcemia and prevent parturient paresis.

\section{MATERIALS AND METHODS}

\section{Cows and Treatments}

Twenty-nine multiparous Jersey cows were randomly assigned to 1 of 3 treatments. Treatments were oral
Table 1. Ingredient and nutrient composition of prepartum diet

\begin{tabular}{|c|c|}
\hline Item & \\
\hline \multicolumn{2}{|l|}{ Ingredient, $\%$ of diet DM } \\
\hline Corn silage & 53.5 \\
\hline High-moisture corn & 22.4 \\
\hline Chopped orchardgrass hay & 13.4 \\
\hline Soybean meal, $44 \% \mathrm{CP}$ & 10.0 \\
\hline Mineral $^{1}$ & 0.7 \\
\hline Yeast cell wall $^{2}$ & 0.1 \\
\hline \multicolumn{2}{|l|}{ Nutrient composition } \\
\hline $\mathrm{DM}, \%$ & $\begin{array}{c}55.6 \\
\% \text { of diet DM }\end{array}$ \\
\hline $\mathrm{CP}$ & 11.6 \\
\hline $\mathrm{ADF}$ & 21.1 \\
\hline NDF & 34.7 \\
\hline $\mathrm{Ca}$ & 0.29 \\
\hline $\mathrm{P}$ & 0.33 \\
\hline $\mathrm{Mg}$ & 0.19 \\
\hline $\mathrm{K}$ & 1.06 \\
\hline $\mathrm{Na}$ & 0.11 \\
\hline $\mathrm{NE}_{\mathrm{L}}, \mathrm{Mcal} / \mathrm{kg}^{3}$ & 1.67 \\
\hline
\end{tabular}

${ }^{1}$ Contained $14.0 \% \mathrm{Ca} ; 9.0 \% \mathrm{P} ; 13.0 \% \mathrm{Na} ; 2.0 \% \mathrm{Mg} ; 0.2 \% \mathrm{~K} ; 2.0 \%$ $\mathrm{S} ; 24 \mathrm{mg} / \mathrm{kg} \mathrm{Co} ; 235 \mathrm{mg} / \mathrm{kg} \mathrm{Cu} ; 80 \mathrm{mg} / \mathrm{kg} \mathrm{I} ; 3,400 \mathrm{mg} / \mathrm{kg} \mathrm{Mn} ; 59 \mathrm{mg} /$ $\mathrm{kg}$ Se; $895 \mathrm{mg} / \mathrm{kg} \mathrm{Zn} ; 297,000 \mathrm{IU} / \mathrm{kg}$ vitamin A; $65,250 \mathrm{IU} / \mathrm{kg}$ vitamin $\mathrm{D}_{3}$; and $900 \mathrm{IU} / \mathrm{kg}$ vitamin $\mathrm{E}$.

${ }^{2}$ MTB 100 (Alltech Inc., Lexington, KY).

${ }^{3}$ Estimated (NRC, 2001).

boluses of corn starch (CON), corn starch plus $15 \mathrm{mg}$ of HyD (DSM, Parsippany, NJ) commercial 25-hydroxyvitamin $\mathrm{D}_{3}(\mathbf{2 5 - O H})$, or corn starch plus $15 \mathrm{mg}$ of cholecalciferol $\left(\mathbf{D}_{\mathbf{3}}\right)$ administered as 2 gel capsules $6 \mathrm{~d}$ before expected calving. If the cow did not calve within $6 \mathrm{~d}$ of bolus treatment, a second dose was administered (4 CON, 5 25-OH, and $7 \mathrm{D}_{3}$ cows were dosed twice). Animals were housed in individual box stalls and fed a common dry cow diet $(\mathrm{Ca} 0.29 \%, \mathrm{P} 0.33 \%$, and $\mathrm{Mg}$ $0.19 \%$ DM basis; Table 1) to achieve $10 \%$ refusals beginning $20 \mathrm{~d}$ before expected calving until parturition. After parturition, animals were relocated to a free-stall facility, group housed, and fed a common lactating cow diet. All procedures used in this experiment were approved by the Virginia Tech Animal Care and Use Committee.

A Foal Alert system (Foal Alert, Acworth, GA) was used to alert project personnel to parturition. A magnetic radio device was sewn to each side of the vulva 2 $\mathrm{d}$ before expected calving. When parturition began, the magnetic connection linking both sides of the device was broken and a radio signal was then sent to a receiver that was linked to a telephone line. This device allowed personnel to arrive for parturition and a blood sample to be collected within minutes of parturition.

\section{Sample Collection}

Jugular blood was collected before feeding on $\mathrm{d}-14$, $-13,-7$, and every day until expected calving; at calving 
(d 0); and 1, 3, 5, 7, 9, 11, 13, 21, and $28 \mathrm{~d}$. Blood was also collected every 2 wk until $84 \mathrm{~d}$ of lactation. Samples were numbered after calving occurred and prepartum samples collected outside of specified times were discarded. If cows were diagnosed by veterinary staff with parturient paresis, a blood sample was collected and treatment was administered. Blood was maintained on ice until centrifugation at $2,200 \times g$ for $20 \mathrm{~min}$. Serum separator tubes (Fisher Scientific, Pittsburgh, PA) were utilized to facilitate serum separation during centrifugation. Serum was harvested and stored frozen for future analysis.

Prepartum feed intake was measured daily. Samples of all feed ingredients and feed refusals were collected weekly. Milk samples were collected on 1, 3, 5, 7, 9, 11, and $13 \mathrm{~d}$ postpartum and stored frozen.

\section{Sample Analysis}

Feed samples and feed refusals were dried at $60^{\circ} \mathrm{C}$ to a constant weight and then ground through a 1-mm screen in a Wiley mill (Arthur H. Thomas, Philadelphia, PA). These samples were analyzed in duplicate for $\mathrm{Ca}$, $\mathrm{P}, \mathrm{Mg}, \mathrm{K}, \mathrm{Na}$, and total Kjeldahl N (AOAC, 1984). Feed and refusals were analyzed sequentially for NDF and ADF according to Van Soest et al. (1991) with the addition of $\alpha$-amylase in the initial wash.

Colorimetric methods were used to analyze all serum samples for Ca (Aresenazo Reagent Set, Pointe Scientific, Canton, MI), inorganic P (Inorganic Phosphorus Reagent, Pointe Scientific), and Mg (Magnesium Reagent Set, Pointe Scientific). Serum 25-OH and PTH were analyzed in samples from $\mathrm{d}-5,-4,-3,-2,-1,0$, $1,3,5,7,9,11$, and 13. A RIA was used to determine 25$\mathrm{OH}$ (25-hydroxyvitamin $\mathrm{D}_{3}$, DiaSorin, Saluggia, Italy) and PTH (N-tact PTH SP, DiaSorin) concentrations. A competitive immunoassay was used to quantify serum OC (Meta Osteocalcin, Quidel Corporation, San Diego, CA) in samples from $d-5,-2,-1,0,1,3,5,7,13,28$, 56 , and 84 .

Milk samples from d 1,3 , and 7 were analyzed for 25-OH concentration by Waters HPLC (Waters, Milford, MA) according to the procedure of Chen et al. (1990). There was no detectable $25-\mathrm{OH}$ found in any of the milk samples analyzed.

Five primiparous Jersey cows were added as part of a second objective within the confines of the first experiment. The primiparous animals were maintained and sampled according to the same protocol as the 29 multiparous animals. The primiparous animals received no treatment but were used to examine the effect of lactation number on $\mathrm{Ca}, \mathrm{P}, \mathrm{Mg}, \mathrm{PTH}, 25-\mathrm{OH}$, and OC with the 9 control multiparous (3 second lactation and 6 greater than second lactation) animals from the first objective.

Data for 2 multiparous cows were removed from analysis: 1 cow on the $25-\mathrm{OH}$ treatment had a displaced abomasum and 1 cow on the $\mathrm{D}_{3}$ treatment was removed because of a breach of experimental protocol, so $n=27$ (9 cows per treatment). Data for another cow on the $25-\mathrm{OH}$ treatment were removed from analysis after 13 DIM due to unexpected failure of the median suspensory ligament and a displaced abomasum (data from 28 through 84 DIM, $\mathrm{n}=26$; 9 cows on CON, 9 cows on $\mathrm{D}_{3}$, and 8 cows on $\left.25-\mathrm{OH}\right)$. There were 3 cows on the $\mathrm{D}_{3}$ treatment and 2 cows on the $25-\mathrm{OH}$ treatment that were diagnosed and treated for parturient paresis within the first $48 \mathrm{~h}$ after parturition.

All cows on this study were concurrently participating in a crossbreeding study. Each animal on this study was bred with mixed Holstein-Jersey semen for the other research trial. The calves from these cows were either Jersey $\times$ Jersey or Holstein $\times$ Jersey crosses. The effect of calf weight on treatment responses was examined statistically but found to be nonsignificant.

\section{Statistical Analysis}

Serum $\mathrm{Ca}, \mathrm{P}, \mathrm{Mg}$, and $\mathrm{OC}$ were analyzed using the Mixed procedure of SAS (9.1, SAS Institute, 2003) with the model

$$
\begin{gathered}
\mathrm{Y}_{\mathrm{ijkl}}=\alpha+\mathrm{b}_{1} \mathrm{X}_{(\mathrm{ij}) \mathrm{k}}+\mathrm{T}_{\mathrm{i}}+\mathrm{L}_{\mathrm{j}}+(\mathrm{TL})_{\mathrm{ij}}+\mathrm{C}_{(\mathrm{ij}) \mathrm{k}} \\
+\mathrm{D}_{1}+(\mathrm{TD})_{\mathrm{il}}+(\mathrm{LD})_{\mathrm{j} 1}+(\mathrm{TLD})_{\mathrm{ijl}}+\mathrm{E}_{\mathrm{ijk} \mathrm{kl}}
\end{gathered}
$$

where $\alpha=$ intercept; $\mathrm{b}_{1}=$ regression of $\mathrm{Y}$ on $\mathrm{X} ; \mathrm{X}_{(\mathrm{ij}) \mathrm{k}}=$ average pretreatment serum concentration of cow k; $\mathrm{T}_{\mathrm{i}}=$ effect of treatment $\left(\mathrm{i}=1\right.$ to 3 ); $\mathrm{L}_{\mathrm{j}}=$ effect of lactation number $(\mathrm{j}=2$ to $>3)$; (TL $)_{\mathrm{ij}}=$ effect of interaction of treatment and lactation; $\mathrm{C}_{(\mathrm{ij}) \mathrm{k}}=$ random effect of cow $\mathrm{k}$ within treatment and lactation; $\mathrm{D}_{1}=$ effect of day relative to calving $(\mathrm{l}=-5$ to 84$)$; (TD $)_{\mathrm{il}}=$ effect of the interaction of treatment and day; $(\mathrm{LD})_{\mathrm{j} 1}=$ effect of the interaction of lactation number and day; $(\mathrm{TLD})_{\mathrm{ijl}}=$ effect of the interaction of treatment, lactation number and day; and $\mathrm{E}_{\mathrm{ijkl}}=$ random residual.

Several covariates were examined to account for the difference in breed of calf carried. This was examined because the variables in question could be influenced by differences in the calf. The current calf weight and previous calf weight were originally in the model as covariates to account for the potential effect of calf breed differences. Calf weights ranged from 21 to $43 \mathrm{~kg}$ but neither covariate was significant.

For all blood analyses, the pooled -14 and $-13 \mathrm{~d}$ preliminary samples were used as a covariate for each measurement when significant. Cows were grouped by 
parity into 3 groups; lactation 2, 3, or $>3$; the last group included both fourth- and fifth-lactation cows. Day was included as a repeated measure, using the ar(1) covariance structure. Prepartum DMI data (d -14 through calving) were analyzed with the above model without the covariate. Preplanned orthogonal contrasts were used to compare the CON treatment to the average of $25-\mathrm{OH}$ and $\mathrm{D}_{3}$ treatments, and to compare the $\mathrm{D}_{3}$ treatment to the $25-\mathrm{OH}$ treatment. Tukey's test was used for pairwise comparison of lactation number least squares means. The model was also used for PTH and 25-OH analysis until d 13 of lactation. For PTH, the slice option was used to determine significant treatment differences within each lactation number and day. Results are reported as least squares means \pm SEM with differences declared significant at $P<0.05$ and trends at $P<0.10$.

For the evaluation of the effect of lactation number, in the primiparous and control cows, on serum $\mathrm{Ca}, \mathrm{P}$, $\mathrm{Mg}$, PTH, 25-OH, and OC the model was

$$
\mathrm{Y}_{\mathrm{ijk}}=\alpha+\mathrm{b}_{1} \mathrm{X}_{(\mathrm{i}) \mathrm{j}}+\mathrm{L}_{\mathrm{i}}+\mathrm{C}_{(\mathrm{i}) \mathrm{j}}+\mathrm{D}_{\mathrm{k}}+(\mathrm{LD})_{\mathrm{ik}}+\mathrm{E}_{\mathrm{ijk}}
$$

where $\alpha=$ intercept; $\mathrm{b}_{1}=$ regression of $\mathrm{Y}$ on $\mathrm{X} ; \mathrm{X}_{(\mathrm{ij}) \mathrm{k}}=$ average precalving serum concentration of $\operatorname{cow} j ; L_{i}=$ effect of lactation number $(\mathrm{i}=1$ to $>3) ; \mathrm{C}_{(\mathrm{i}) \mathrm{j}}=$ random effect of cow $\mathrm{k}$ within lactation; $\mathrm{D}_{\mathrm{k}}=$ effect of day relative to calving ( $\mathrm{k}=-5$ to 84$) ;(\mathrm{LD})_{\mathrm{ik}}=$ effect of the interaction of lactation number and day; and $\mathrm{E}_{\mathrm{ijk}}=$ random residual. Tukey's test was used for pairwise comparison.

The pooled -14 and $-13 \mathrm{~d}$ preliminary samples were used as a covariate for each measurement when significant. Cows were grouped by parity into 3 groups; lactation 1,2, and $>2$; the last included 2 third-, 3 fourth-, and 1 fifth-lactation cows. Group size was small. However, previous literature (Shappell et al., 1986; Hodnett et al., 1992) has shown this is acceptable when examining variables such as serum $\mathrm{Ca}, \mathrm{P}$, and $\mathrm{PTH}$ concentrations.

\section{RESULTS AND DISCUSSION}

Ingredient and nutrient composition of the prepartum diet is reported in Table 1. Prepartum DMI (from $-14 \mathrm{~d}$ through calving) averaged $9.6 \pm 0.77 \mathrm{~kg} / \mathrm{d}$. We observed the expected significant effect of day, a 20\% decline as calving approached, but DMI was not affected by treatment, parity, or 2- and 3-way interactions of treatment, parity, and day. Based on analyzed nutrient concentration and measured DMI, the diet supplied sufficient available $\mathrm{Ca}, \mathrm{Mg}$, and $\mathrm{P}$ to meet the cows' requirements and supplied energy and protein in excess of requirements (NRC, 2001).
Table 2. Effect of parity on serum variables from Jersey cows beginning in the prepartum period

\begin{tabular}{|c|c|c|c|c|c|}
\hline \multirow[b]{2}{*}{ Variable } & \multicolumn{3}{|c|}{ Parity number } & \multirow[b]{2}{*}{ SEM } & \multirow[b]{2}{*}{$P<$} \\
\hline & 1 & 2 & $>2$ & & \\
\hline Number of cows & 5 & 3 & 6 & & \\
\hline $\mathrm{Ca},{ }^{1} \mathrm{mg} / \mathrm{dL}$ & 9.8 & 9.8 & 9.4 & 0.36 & 0.48 \\
\hline $\mathrm{P},{ }^{1} \mathrm{mg} / \mathrm{dL}$ & 4.7 & 4.8 & 4.4 & 0.18 & 0.13 \\
\hline $\mathrm{Mg},{ }^{1} \mathrm{mg} / \mathrm{dL}$ & $2.4^{\mathrm{a}}$ & 2.5 & $2.6^{\mathrm{b}}$ & 0.05 & 0.01 \\
\hline Parathyroid hormone, ${ }^{2} \mathrm{pg} / \mathrm{mL}$ & 9.7 & 7.8 & 10.3 & 1.0 & 0.13 \\
\hline 25-Hydroxyvitamin $\mathrm{D}_{3},{ }^{2} \mathrm{ng} / \mathrm{mL}$ & 64.8 & 64.5 & 68.4 & 5.8 & 0.75 \\
\hline Osteocalcin,${ }^{3} \mathrm{ng} / \mathrm{mL}$ & $48.3^{\mathrm{a}}$ & $32.0^{\mathrm{b}}$ & $22.3^{\mathrm{c}}$ & 3.3 & 0.0001 \\
\hline \multicolumn{6}{|c|}{${ }^{a-c}$ Values with different superscripts in the same row differed at } \\
\hline \multicolumn{6}{|c|}{${ }^{1}$ Evaluated through 84 DIM. } \\
\hline \multicolumn{6}{|l|}{${ }^{2}$ Evaluated through 13 DIM. } \\
\hline${ }^{3}$ Evaluated through 84 DIM. & & & & & \\
\hline
\end{tabular}

\section{Effect of Parity}

Lactation number had no effect on serum Ca, P, PTH, or 25-OH concentration (Table 2). This is in contrast to other studies (Moore et al., 2000; Chan et al., 2006) that reported greater serum $\mathrm{Ca}$ concentrations in primiparous cows compared with multiparous cows. Moore et al. (2000) found lower serum PTH and 25-OH concentrations in primiparous cows compared with multiparous cows in a study that examined dietary cation-anion difference. In the present study first-lactation cows had lower serum $\mathrm{Mg}$ concentrations compared with cows with $>2$ lactations.

Serum OC concentration was greatest in first-lactation cows compared with all other lactations (Table 2, Figure 1), and cows in their second lactation had greater serum OC concentrations than those with $>2$ lactations. Liesegang et al. (2000) first reported that OC is affected by age in a study examining the effect of low and high milk yields in lactating Brown Swiss cows between the ages of 5 and $13 \mathrm{yr}$. This study did not specify OC concentration differences between the ages. A study by Kamiya et al. (2005) reported similar results to the present study with greater concentrations of $\mathrm{OC}$ and a marker of bone resorption in primiparous cows from $-13 \mathrm{~d}$ prepartum to $3 \mathrm{~d}$ postpartum. Moore et al. (2000) observed that concentration of hydroxyproline, a marker of bone resorption, was greater in primiparous cows than in multiparous cows. The results from the present study and the Moore et al. (2000) and Kamiya et al. (2005) studies taken together would suggest that although primiparous cows resorb more bone compared with multiparous cows, they also replace that bone throughout lactation.

Keene et al. (2004) measured bone mineral content (BMC) in cadaver Holstein metacarpal and caudal vertebrae to evaluate effects of parity. Total BMC concentration (ash, \% of bone DM) was not affected by parity 


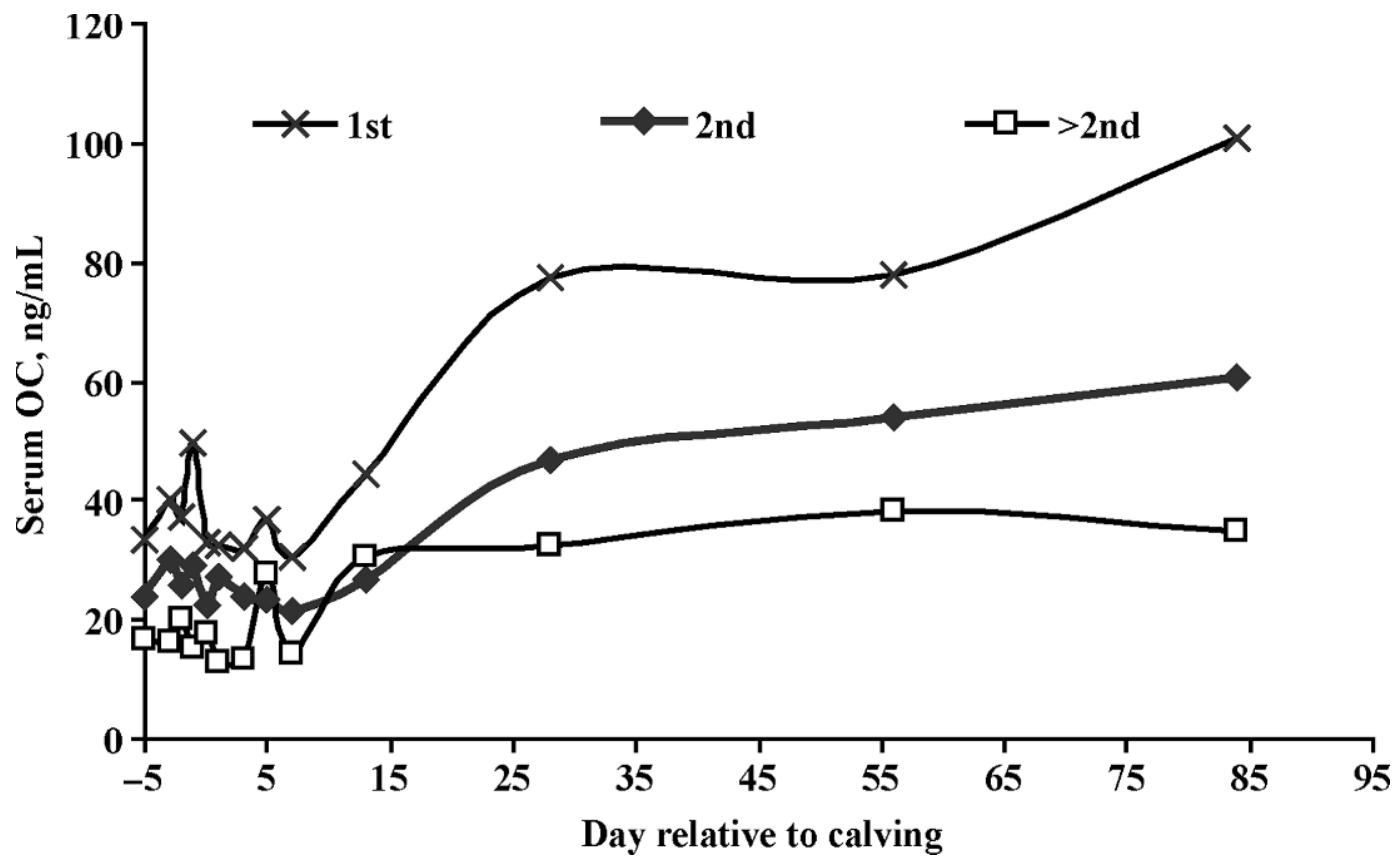

Figure 1. Effect of parity on serum osteocalcin $(\mathrm{OC})$ concentration from -5 to $84 \mathrm{~d}$ relative to parturition with no treatment administered $\mathrm{SEM}=17.2 ; P<0.0001$ for parity; parity by day $P=0.85$.

but $\mathrm{Ca}$ and $\mathrm{P}$ concentration of the metacarpal vertebrae increased with parity. This could indicate less resorption of these minerals in multiparous animals. However, the results of Keene et al. (2004) are likely specific to cull dairy animals and BMC may not be the most appropriate evaluation of total bone mineral reserves due to differences in bone mineral mass over time (Beighle, 1999).

\section{Serum $\mathrm{Ca}, \boldsymbol{P}$, and $\mathrm{Mg}$}

There were no treatment (Table 3) or treatment by time interaction effects on serum Ca or serum $\mathrm{P}$ (Figure $2, \mathrm{~A}$ and $\mathrm{B})$. There was an interaction of parity and time for serum $\mathrm{Ca}$ concentration $(P<0.01)$. The $>3$ lactations group had lower serum $\mathrm{Ca}$ concentration on d 0 and 1 compared with both the second- and third-

Table 3. Effect of treatment on serum variables from 27 Jersey cows dosed prepartum with corn starch (CON), 25-hydroxyvitamin $\mathrm{D}_{3}(25$ $\mathrm{OH})$, or vitamin $\mathrm{D}_{3}\left(\mathrm{D}_{3}\right)$

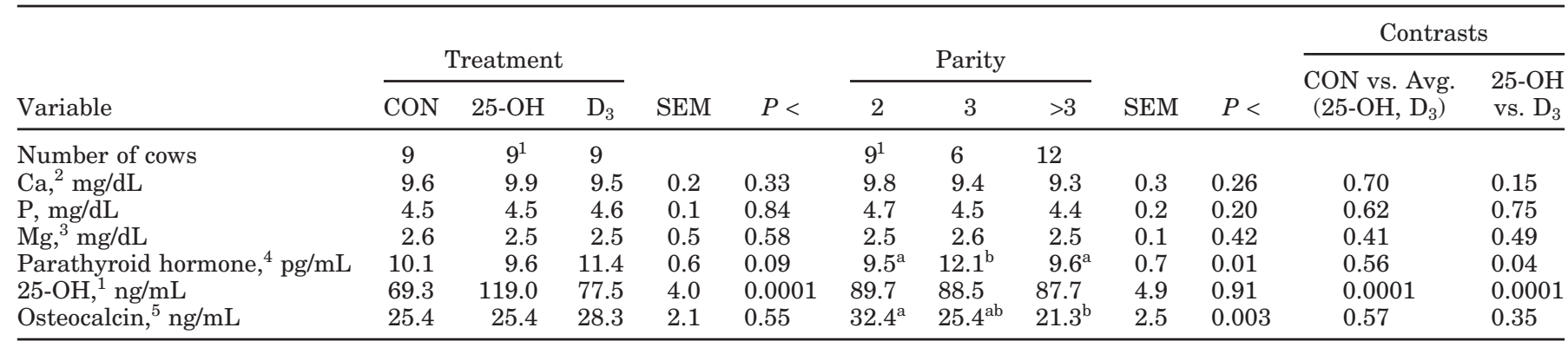

${ }^{\mathrm{a}, \mathrm{b}}$ Values for parity with different superscripts in the same row differed at $P<0.05$.

${ }^{1}$ Evaluated through 13 DIM; 1 cow was culled after 13 DIM, 8 cows evaluated until 84 DIM.

${ }^{2}$ Parity number $\times$ day interaction was significant $(P<0.01)$.

${ }^{3}$ Treatment $\times$ parity number interaction tended to be significant $(P<0.09)$.

${ }^{4}$ Evaluated through 13 DIM; treatment $\times$ parity number interaction was significant $(P<0.02)$.

${ }^{5}$ Parity number $\times$ day interaction was significant $(P<0.04)$. 
A.

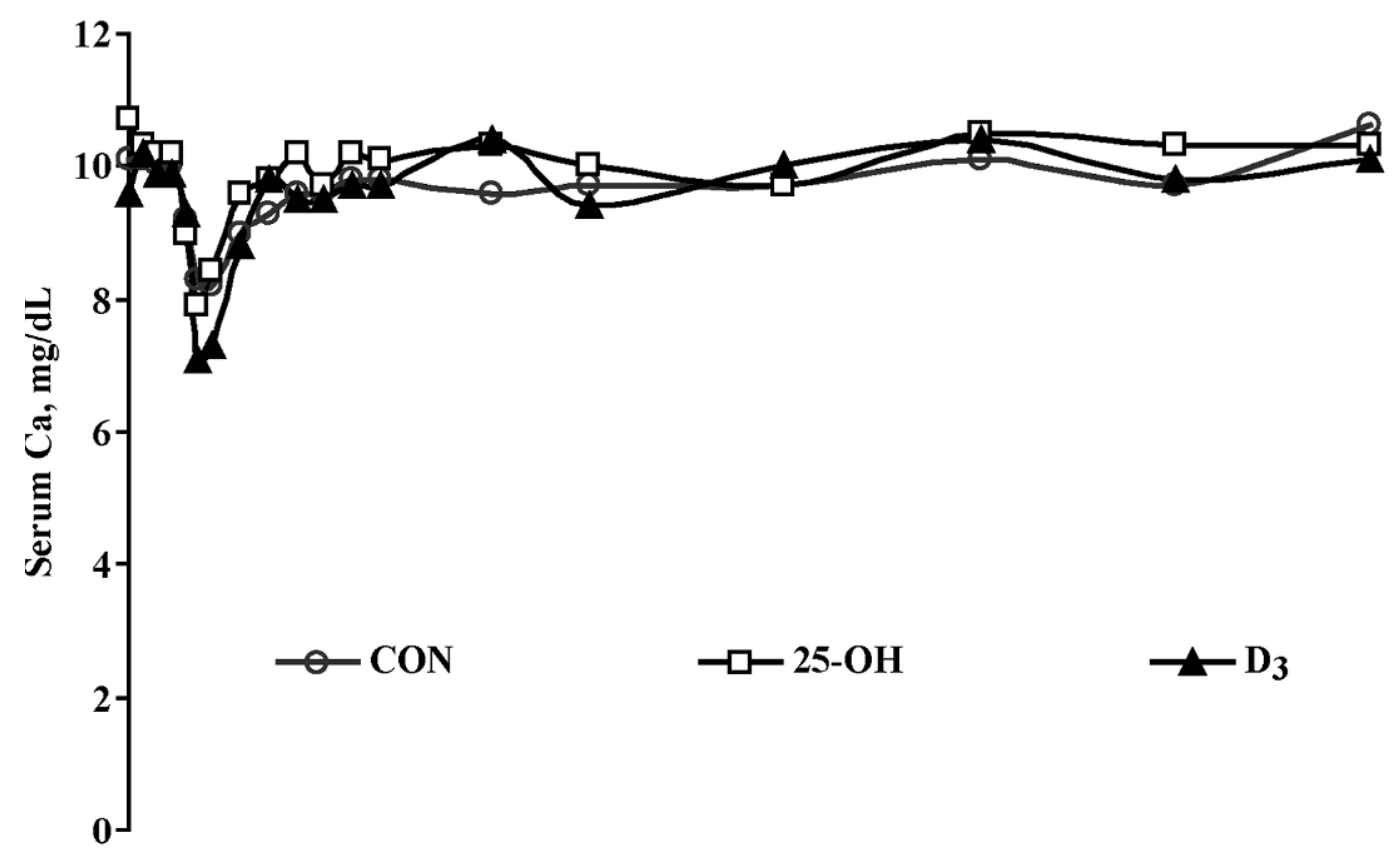

B.

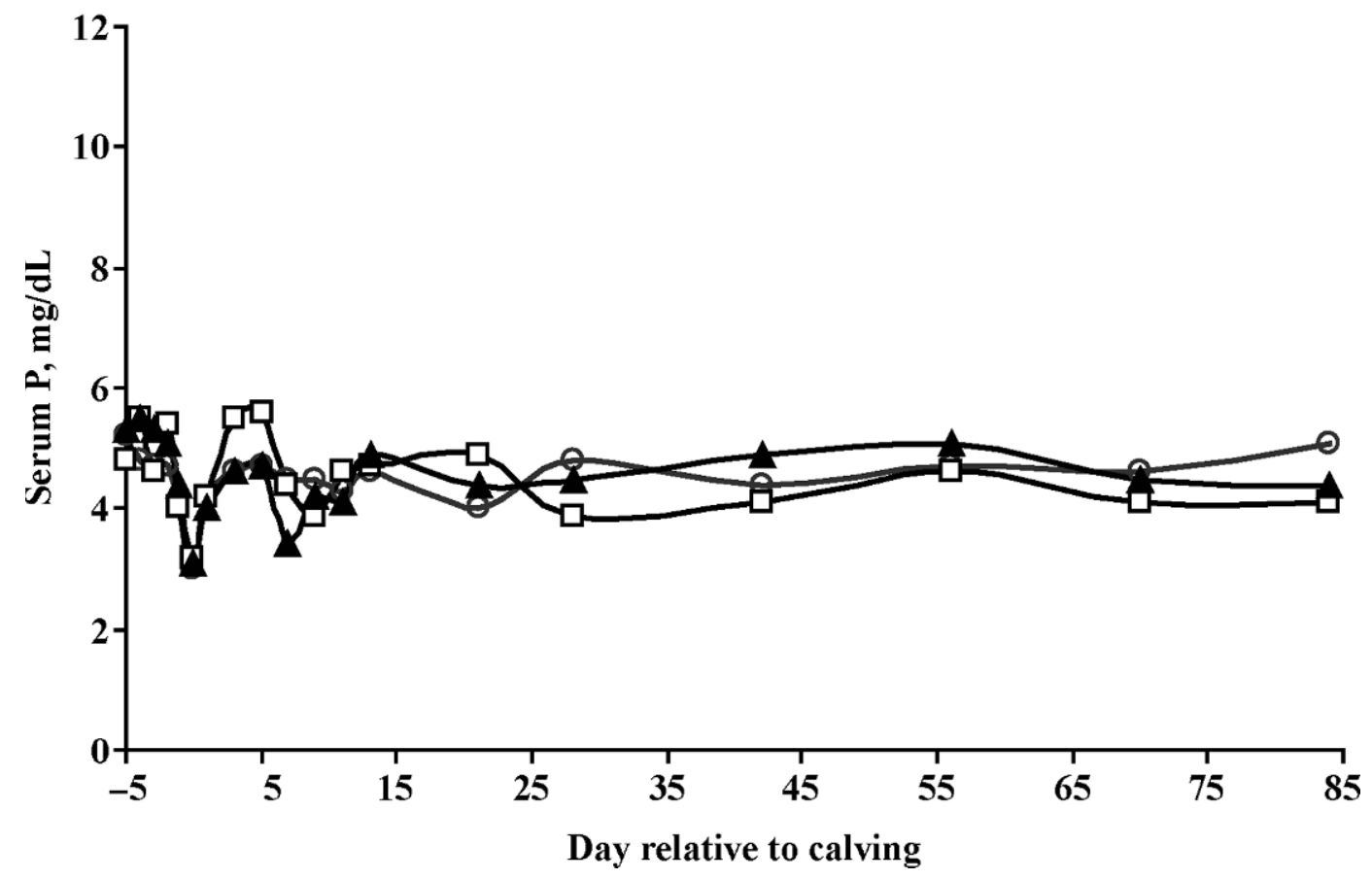

Figure 2. Effect of time and treatment on serum A) Ca and B) $\mathrm{P}$ concentration in 27 Jersey cows dosed prepartum with corn starch (CON), 25-hydroxyvitamin $\mathrm{D}_{3}(25-\mathrm{OH})$, or vitamin $\mathrm{D}_{3}\left(\mathrm{D}_{3}\right)$. SEM $=0.42$.

lactation groups. Serum $\mathrm{Ca}$ and $\mathrm{P}$ were both different over time and were within the normal concentration range for adult ruminants ( 8 to $10 \mathrm{mg} / \mathrm{dL}$ and 4 to 8 $\mathrm{mg} / \mathrm{dL}$, respectively), but were unaffected by treatment. Olson et al. (1973b) similarly found that serum Ca and
$\mathrm{P}$ concentrations were not different in cows injected with 4.0 or $8.0 \mathrm{mg}$ of $25-\mathrm{OH}$ in sesame oil carrier between $72 \mathrm{~h}$ and $10 \mathrm{~d}$ before calving compared with controls. A study by Rivera et al. (2005) examined oral dosing of beef heifers with $0,10,100$, or $1,000 \mathrm{mg}$ of 
25-OH in efforts to improve meat tenderness. At daily doses of 100 or $1,000 \mathrm{mg}$ of $25-\mathrm{OH}$, serum Ca concentration increased in treated beef heifers compared with controls. The oral dose of $25-\mathrm{OH}$ needed to increase blood $\mathrm{Ca}$ was much greater than used in the present study.

The DHVD analog appears to increase serum Ca and $\mathrm{P}$ concentrations when administered alone or in conjunction with 25-OH. Cows injected every $5 \mathrm{~d}$ beginning $15 \mathrm{~d}$ before parturition with $0.5 \mathrm{mg}$ of DHVD and $4.0 \mathrm{mg}$ of 25-OH had greater serum $\mathrm{Ca}$ and $\mathrm{P}$ concentrations at 2, 3, 5, and $7 \mathrm{~d}$ posttreatment compared with control cows (Hodnett et al., 1992). Braithwaite (1978) also found that injecting sheep with $5 \mu \mathrm{g} / \mathrm{d}$ of DHVD for 10 $\mathrm{d}$ beginning $1 \mathrm{wk}$ after lambing increased serum $\mathrm{Ca}$ $(11.6 \mathrm{mg} / \mathrm{dL})$ and $\mathrm{P}(10.8 \mathrm{mg} / \mathrm{dL})$ concentrations compared with control $(9.2$ and $8.4 \mathrm{mg} / \mathrm{dL}$ for $\mathrm{Ca}$ and $\mathrm{P}$, respectively) treated sheep. An intravaginal dose of 1 $\mu \mathrm{g}$ of DHVD increased plasma Ca concentration from 12 to $72 \mathrm{~h}$ after treatment compared with the 0 -h sample (Okura et al., 2004). Taken with the present data it appears that both the timing of administration of the vitamin $\mathrm{D}$ analog and the form are critical factors. In the present study, both timing of administration as well as the dose and form of vitamin D administered could be responsible for the failure to increase serum $\mathrm{Ca}$ and $\mathrm{P}$ concentrations.

Serum Mg concentration was not affected by treatment. The interaction of treatment and parity number tended to be significant $(P<0.09)$ for serum $\mathrm{Mg}$ concentration. The treatment by parity interaction can be explained by the third-lactation cows behaving differently on the 25-OH treatment. The third-lactation cows treated with 25-OH had lower serum Mg concentrations compared with the other treatments. A biological explanation for this response is not obvious.

\section{Serum Hormones}

As expected, concentration of $25-\mathrm{OH}$ was greater in serum from cows dosed with 25-OH compared with cows dosed with $\mathrm{CON}$ and $\mathrm{D}_{3}$ (Table 3 ). There was no effect of time by treatment interaction (Figure 3 ) or lactation number on serum 25-OH concentration. Parathyroid hormone concentration was lower in $25-\mathrm{OH}$-dosed cows when compared with the D3-dosed cows (Table 3). There was a treatment by parity interaction for PTH concentration whereby cows in the $>3$ lactations group dosed with 25-OH had lower serum PTH compared with other $>3$ lactation cows (Figure 4).

Similarly, Rivera et al. (2005) observed that the blood concentration of $25-\mathrm{OH}$ increased when heifers were treated with exogenous $25-\mathrm{OH}$. However, in the present study the increase in serum $25-\mathrm{OH}$ in the $25-\mathrm{OH}$ treated

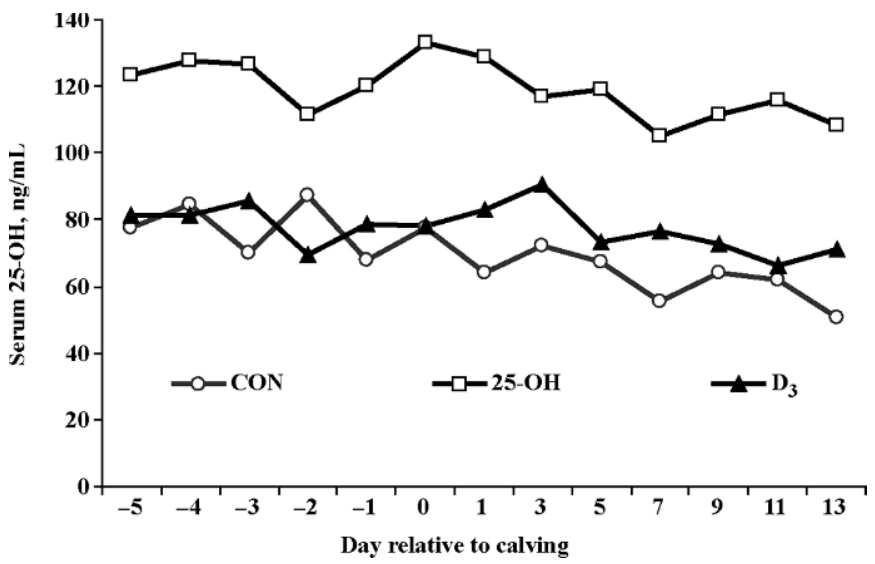

Figure 3. Serum 25-hydroxyvitamin $\mathrm{D}_{3}(25-\mathrm{OH})$ concentration from $-5 \mathrm{~d}$ prepartum until d 13 of lactation in 27 Jersey cows dosed prepartum with corn starch $(\mathrm{CON}), 25$-hydroxyvitamin $\mathrm{D}_{3}(25-\mathrm{OH})$, or vitamin $\mathrm{D}_{3}\left(\mathrm{D}_{3}\right) . \mathrm{SEM}=10.1$.

group did not result in an increase in serum Ca concentration. The lack of response in serum Ca suggests that these cows did not sufficiently convert $25-\mathrm{OH}$ into the active compound DHVD, but rather catabolized the hormone. This theory is corroborated by serum PTH concentrations tending to be lower in the 25-OH-treated cows compared with CON and D3 cows. High circulating PTH concentrations depress catabolic enzymes in the kidney that metabolize 25-OH to inactive metabolites (Goff et al., 1991). In the present study where PTH concentration was low, 25-OH concentration was high, and there was no effect of 25-OH dosing on Ca concentration, the authors speculate that the catabolic enzymes were active and degraded the $25-\mathrm{OH}$.

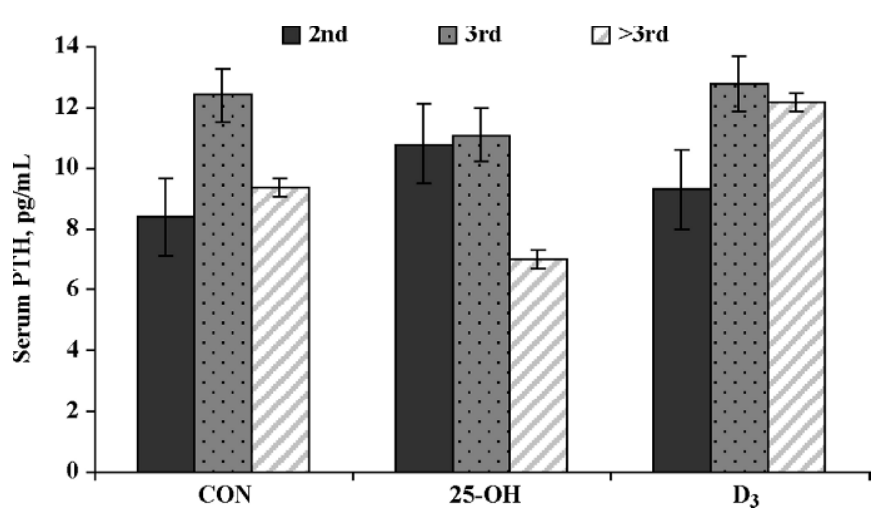

Figure 4. Effect of parity and treatment on serum parathyroid hormone (PTH) concentration in 27 Jersey cows dosed prepartum with corn starch $(\mathrm{CON}), 25$-hydroxyvitamin $\mathrm{D}_{3}(25-\mathrm{OH})$, or vitamin $\mathrm{D}_{3}\left(\mathrm{D}_{3}\right)$. Interaction of treatment $\times$ parity, $P<0.02$. 


\section{Blood Marker of Bone Metabolism}

In the present study there was no effect of treatment (Table 3) on serum OC concentration. In contrast, others have observed an increase in OC concentration when dosing with DHVD in humans and sheep (Markowitz et al., 1987; Fortune et al., 1989). The response of the bovine may differ from these species as Naito et al. (1990) observed no correlation between blood OC and DHVD concentration in preparturient and postparturient cows. The cows in the study of Naito et al. (1990) were not administered exogenous vitamin $\mathrm{D}$ in any form. In the present study, the authors suggest that although serum $25-\mathrm{OH}$ concentration increased in cows treated with $25-\mathrm{OH}$, the $25-\mathrm{OH}$ was not converted to DHVD sufficiently to stimulate bone formation.

Second-lactation cows had greater serum concentrations of OC compared with cows in the 3 or $>3$ lactation groups (Table 3 ). As OC is a marker of osteoblast activity resulting in bone formation (Farrugia et al., 1989), the results from the present study were expected because osteoblast numbers decrease with age (Liao et al., 1990). Also, osteoblasts are the only bone cells to contain DHVD receptors (Liao et al., 1990), and Horst et al. (1990) demonstrated that bone from older rats contains fewer DHVD receptors than bone from young rats.

\section{CONCLUSIONS}

It appears that within the control treatment the firstlactation animals were more active in bone formation regardless of serum $\mathrm{Ca}$ concentration compared with multiparous cows. The increase in serum $25-\mathrm{OH}$ in the group treated with $25-\mathrm{OH}$ did not result in an increase in serum $\mathrm{Ca}$ concentration. The lack of response in serum Ca suggests that conversion of $25-\mathrm{OH}$ into the active compound DHVD was insufficient, perhaps due to catabolism of this compound. This theory is corroborated by serum PTH concentrations tending to be lower in the 25-OH-treated cows compared with $\mathrm{CON}$ and $\mathrm{D}_{3}$ cows. Although a $60 \%$ increase in serum $25-\mathrm{OH}$ was observed due to a single oral dose of $25-\mathrm{OH}$ before calving, the amount administered in this study was apparently not sufficient for improvement in Ca homeostasis at parturition. Oral dosing with $15 \mathrm{mg}$ of $25-\mathrm{OH}$ at 6 $\mathrm{d}$ before expected calving is not justified.

\section{ACKNOWLEDGMENTS}

The authors would like to thank DSM Nutrition for providing the 25-hydroxyvitamin $\mathrm{D}_{3}$ product and for research support for the project. The work of Virginia Tech staff and students William Saville, Curtis Caldwell, Shane Brannock, Ashley Peterson, Allison Smith,
Shelly Slump, and especially Wendy Wark in organizing, analyzing, sampling, and technical support is greatly appreciated.

\section{REFERENCES}

Association of Official Analytical Chemists. 1984. Official Methods of Analysis. 14th ed. AOAC, Arlington VA.

Beighle, D. E. 1999. The effects of gestation and lactation on bone calcium, phosphorus and magnesium in dairy cows. J. S. Afr. Vet. Assoc. 70:142-146.

Braithwaite, G. D. 1978. The effect of 1- $\alpha$-hydroxycholecalciferol on calcium and phosphorus metabolism in the lactating ewe. Br. J. Nutr. 40:387-392.

Chan, P. S., J. W. West, and J. K. Bernard. 2006. Effect of prepartum dietary calcium on intake and serum and urinary mineral concentrations of cows. J. Dairy Sci. 89:704-713.

Chen, T. C., A. K. Turner, and M. F. Holick. 1990. Methods for the determination of the circulating concentration of 25-hydroxyvitamin D. J. Nutr. Biochem. 1:315-319.

Farrugia, W., C. L. Fortune, J. Heath, I. W. Caple, and J. D. Wark. 1989. Osteocalcin as an index of osteoblast function during and after ovine pregnancy. Endocrinology 125:2785-2790.

Fortune, C. L., W. Farrugia, J. Tresham, B. A. Scogins, and J. D. Wark. 1989. Hormonal regulation of osteocalcin plasma production and clearance in sheep. Endocrinology 124:2785-2790.

Goff, J. P. 2000. Pathophysiology of calcium and phosphorus disorders. Metabolic disorders of ruminants. Vet. Clin. North Am. Food Anim. Pract. 16:319-337.

Goff, J. P., T. A. Reinhardt, D. C. Beitz, and R. L. Horst. 1995. Breed affects tissue vitamin $\mathrm{D}$ receptor concentration in periparturient dairy cows: A milk fever risk factor? J. Dairy Sci. 78(Suppl. 1):184. (Abstr.)

Goff, J. P., T. A. Reinhardt, and R. L. Horst. 1991. Enzymes and factors controlling vitamin D metabolism and action in normal and milk fever cows. J. Dairy Sci. 74:4022-4032.

Hibbs, J. W., and W. D. Pounden. 1951. The relation of atmospheric pressure to the occurrence of milk fever. J. Am. Vet. Med. Assoc. 891:383-384.

Hodnett, D. W., N. A. Jorgensen, and H. F. Deluca. 1992. $1 \alpha-H y-$ droxyvitamin $\mathrm{D}_{3}$ plus 25 -hydroxyvitamin $\mathrm{D}_{3}$ reduces parturient paresis in dairy cows fed high dietary calcium. J. Dairy Sci. 75:485-491.

Horst, R. L., J. P. Goff, and T. A. Reinhardt. 1990. Advancing age results in reduction of intestinal and bone $1,25(\mathrm{OH})_{2} \mathrm{D}$ receptor. Endocrinology 126:1053-1057.

Horst, R. L., J. P. Goff, and T. A. Reinhardt. 1994. Calcium and vitamin D metabolism in the dairy cow. J. Dairy Sci. 77:19361951.

Horst, R. L., K. Hove, E. T. Littledike, and T. A. Reinhardt. 1983. Plasma concentrations of 1,25-dihydroxyvitamin D, 1,24R,25-trihydroxyvitamin $\mathrm{D}_{3}$ after their administration to dairy cows. J. Dairy Sci. 66:1455-1460.

Kamiya, Y., M. Kamiya, M. Tanaka, and S. Shioya. 2005. Effects of calcium intake and parity on plasma minerals and bone turnover around parturition. Anim. Sci. J. 76:325-330.

Keene, B. E., K. F. Knowlton, M. L. McGilliard, L. A. Lawrence, S. M. Nickols-Richardson, J. H. Wilson, A. M. Rutledge, L. R. McDowell, and M. E. Van Amburgh. 2004. Measures of bone mineral content in mature dairy cows. J. Dairy Sci. 87:3816-3825.

Liao, J., K. Ozono, T. Sone, D. P. McDonnell, and J. P. Pile. 1990. Vitamin D receptor interaction with specific DNA requires a nuclear protein and 1,25-dihydroxyvitamin $\mathrm{D}_{3}$. Proc. Natl. Acad. Sci. USA 87:9751-9755.

Liesegang, A., R. Eicher, M. L. Sassi, J. Risteli, M. Kraenzlin, J. L. Riond, and M. Wanner. 2000. Biochemical markers of bone formation and resorption around parturition and during lactation in dairy cows with high and low standard milk yields. J. Dairy Sci. 83:1773-1781. 
Littledike, E. T., G. W. Engstrom, and M. Sachs. 1986. Sequential sampling and analysis of renal hydroxylase activities of cattle given $1 \alpha$-hydroxyvitamin $\mathrm{D}_{3}$. J. Dairy Sci. 69:990-997.

Littledike, E. T., and R. L. Horst. 1982. Vitamin $\mathrm{D}_{3}$ toxicity in dairy cows. J. Dairy Sci. 65:749-759.

Markowitz, M. E., C. M. Gundberg, and J. F. Rosen. 1987. The circadian rhythm of serum osteocalcin concentrations: Effects of 1,25dihydroxyvitamin D administration. Calcif. Tissue Int. 40:179183.

Moore, S. J., M. J. VandeHaar, B. K. Sharma, T. E. Pilbeam, D. K. Beede, H. F. Bucholtz, J. S. Liesman, R. L. Horst, and J. P. Goff. 2000. Effects of altering dietary cation anion difference on calcium and energy metabolism in prepartum cows. J. Dairy Sci. 83:2095-2104.

NAHMS. 2002. Dairy 2002. Part 1: Reference of Dairy Health and Management in the United States 2002. http://www.aphis.usda.gov/vs/ceah/ncahs/nahms/dairy/dairy02/Dairy02Pt1.pdf Accessed Dec. 19, 2007.

Naito, Y., N. Shindo, R. Sato, and D. Murakami. 1990. Plasma osteocalcin in preparturient and postparturient cows: Correlation with plasma 1,25-dihydroxyvitamin $\mathrm{D}_{3}$, calcium and inorganic phosphorus. J. Dairy Sci. 73:3481-3484.

National Research Council. 2001. Nutrient Requirements of Dairy Cattle. 7th rev. ed. Natl. Acad. Sci., Washington, DC.
Okura, N., N. Yamagishi, Y. Naito, K. Kanno, and M. Koiwa. 2004. Technical Note: Vaginal absorption of $1,25(\mathrm{OH})_{2} \mathrm{D}_{3}$ in cattle. J. Dairy Sci. 87:2416-2419.

Olson, W. G., N. A. Jorgensen, A. N. Bringe, L. H. Schultz, and H. F. Deluca. 1973b. 25-Hydroxycholecalciferol $\left(25-\mathrm{OHD}_{3}\right)$ I. Treatment for parturient paresis. J. Dairy Sci. 56:885-888.

Olson, W. G., N. A. Jorgensen, L. H. Schultz, and H. F. Deluca. 1973a. 25-Hydroxycholecalciferol $\left(25-\mathrm{OH} \mathrm{D}_{3}\right)$ II. Efficacy of parenteral administration in prevention of parturient paresis. J. Dairy Sci. 56:889-895.

Rivera, J. D., S. E. Bachman, M. E. Hubbert, M. E. Branine, R. L. Horst, S. N. Williams, and M. L. Galyean. 2005. Serum and tissue concentrations of vitamin $\mathrm{D}$ metabolites in beef heifers after buccal dosing of 25-hydroxyvitamin $\mathrm{D}_{3}$. J. Dairy Sci. 88:1364-1369.

Shappell, N. W., J. H. Herbein, L. J. Deftos, and R. J. Aiello. 1986. Effects of dietary calcium and age on parathyroid hormone, calcitonin and serum and milk minerals in periparturient dairy cows. J. Nutr. 117:201-207.

Van Soest, P. J., J. B. Robertson, and B. A. Lewis. 1991. Symposium: Carbohydrate methodology, metabolism, and nutritional implication in dairy cattle. Methods for dietary fiber, neutral detergent fiber, and nonstarch polysaccharides in relation to animal nutrition. J. Dairy Sci. 74:3583-3597. 